\title{
Law and Politics: Montesquieu and the 4 Schools of Legal Theory
}

\author{
Jan-Erik Lane \\ Public Policy Institute, BELGRADE, Yangon, Myanmar \\ Email: janeklane@gmail.com
}

How to cite this paper: Lane, J.-E. (2017) Law and Politics: Montesquieu and the 4 Schools of Legal Theory. Open Access Library Journal, 4: e4092.

https://doi.org/10.4236/oalib.1104092

Received: October 30, 2017

Accepted: November 25, 2017

Published: November 28, 2017

Copyright $\odot 2017$ by author and Open Access Library Inc.

This work is licensed under the Creative Commons Attribution International License (CC BY 4.0).

http://creativecommons.org/licenses/by/4.0/

\section{(c) (i) Open Access}

\begin{abstract}
The theory of separation of powers in the state by Montesquieu (1748) is the longest serving theory in real politics, maintaining its relevance for more than 200 hundred years. Most constitutions in written form follow his paradigm, at least from a formal point of view. Constitutional democracies certainly apply or enforce Montesquieu's ideal-type for rule of law and political stability. How does this great political theory fit with the major schools in jurisprudence about what is law and the role of judges in adjudication? This question has never been raised, but it is as essential to Montesquieu's paradigm as the changing relations between executive and legislature in for instance parliamentarism and presidentialism.
\end{abstract}

\section{Subject Areas}

Politics

\section{Keywords}

Montesquieu, Natural Law, Legal Positivism, Legal Realism, Legal Pragmatism

\section{Introduction}

Since Montesquieu [1], the social sciences are very much interested in law and its impact upon politics. The distinctions between executive, legislature and judiciary remain valid today, very much according to the Montesquieu legacy. Trias politica-the theory of separation of political powers-is essential in the analysis of all constitutions and constitutional reforms [2]. Yet, in none of the four great legal philosophies-or schools of jurisprudence-is there a balanced view of the relations between the executive, legislature and judiciary. Beneath the controversy between legal theories, there is the Montesquieu problematic of a balance between the three state powers [3]. Neither natural law theory nor legal 
positivism, nor legal realism nor legal pragmatism achieves such a Montesquieu balance.

Montesquieu's theory of the separation of powers is analytical tool for understanding why liberty is low in Central Asia and East Asia, from Petersburg to Shanghai, as well as in the Koranic world with both Sunnis and Shias. Taking out India with its British legacy, this is actually the same world that was called "Oriental Despotism" by the French Enlightenment [4]. Trias politica offers also a moral tool for reforming several countries in the world, where judicial independence is compromised.

\subsection{Trias Politica}

The theory of three different state competences antedates democratic theory, but has been integrated into it in the form of constitutional democracy. All viable constitutions-formal or informal-adhere to the Montesquieu distinctions as long as they deliver rule of law. The balance between the state organs or state powers depends not only upon the structure of the executive and its relation to the legislature, but also upon the prevailing legal doctrine, as taught by the main school of legal theory.

To understand the fundamental importance of the separation of powers doctrine, one may consider what it would exclude when enforced. We would eliminate:

i) Decretismo

ii) Rule by ordinances or regulations

iii) Military rule

iv) Emergency law giving power

v) Executive orders

vi) Habeas Corpus violations

vii) Impossibility of appeal

viii) No complaints procedures

ix) Dependency of judges

x) Fakes trials.

xi) Arbitrary arrests and prison sentences.

xii) Restrictions on defense of accused.

Trias politica is necessary for rule of law. What, then, is law? Everybody agrees on one point, namely that law comprises norms, but then the disagreements start about what norms constitute legal norms, and how to study them [5].

\section{2. "Law" and Legal Schools}

"Norm" is an ambiguous word, meaning either regular behaviour or normative sentence, or command. By "legal norm", one may refer to a paragraph in the constitution for instance, or an institution in society' legal functioning system. norms, and how to study them.

"Norm" is an ambiguous word, meaning either regular behaviour or normative sentence, or command. By "legal norm", one may refer to a paragraph in the 
constitution for instance, or an institution in society' legal functioning system. The same ambiguity is to be found when the legal order or system is called a collection of "rules", as a rule may be an instruction written down in a law book or the actual regularly that satisfies the written rule. When norms or rules are obeyed or backed by sanctions, one speaks about "institutions", or "institutionalization".

A reasonable definition of "law" is that it refers to ordered couples of norm sentences and behaviour regularities, i.e. <norm, enforcement>. Now, let us examine a doctrine that conceptualizes law as morals, denying the separation of moral and legal norms. Take the legal system or order of India as an example. If it is a matter of constitutional law, then one would have to be informed about three things:

i) Written constitution, the text and supplements;

ii) The rulings of the constitutional court, i.e. the application and interpretation of its judges;

iii) The extent to which the norms or rules are met with compliance.

\subsection{IS- and OUGHT-Jurisprudence}

All of this is the IS-jurisprudence. Constitutional analysis would look into the existence of obsolete rules, the conflict of norms and the political struggle over constitutional change and interstate divergence over legal interpretation. However, the separation of powers is also suitable for OUGHT-jurisprudence, suggesting that especially the integrity of the judiciary is of crucial importance for the respect of both human rights and the democratic regime.

\section{Natural Law School: Favouring the Judicial Branch}

The natural law scholars claim that there is a set of norms laid down in reason somehow. Right reason offers the law of humanity, transcending so-called positive law, i.e. country or national law. What is natural law that has become so popular in the new moralism in the social sciences? The natural law scholars claim that there is a set of norms laid down in reason somehow. Right reason offers the law of humanity, transcending so-called positive law, i.e. country or national law. The natural law tradition stretches from Ancient Stoicism over Hugo Grotius to Robert Nozick and Ronald Dworkin [6]. But it is not really jurisprudence but moral theory, backed by religion, as with Roman lawyers.

Natural law belongs to OUGHT-jurisprudence. It has a long fascinating history including scholars like Lipsius, Locke and Finnis. Focusing upon the concept of rights, it developed slowly into a democratic theory, i.e. the human rights doctrine with Thomas Paine [7]. The beginnings of natural law theorizing are to be found in Greek-Roman philosophy from the Ancient period, especially with the Pre-Socrates and the Post-Socrates [8].

\subsection{Stoicism versus Epicurism}

Epicurism, in the hand, had its core in atomism and adhered to its implications, 
such as determinism and naturalism-Demokritos' atom theory. The Universe followed its laws and humans were driven by the search for pleasure and the avoidance of pain. Only reason could the emotions towards enlightened self-interest seeking. Human life was basically determined just as nature, but the consolation was given by reason, recommending a life in emotional balance of rational insight. Law was merely the norms imposed by the local community or government in place, as with Hobbes and Spinoza. On the other hand, Stoicism had spiritual origins, which made it attractive to later Christian theology. The entire world is a kind of soul, which humans are members of. This soul is a gigantic community of everything, nature and living organisms. To be a member renders every human immunities, i.e. the human rights from sociability. Life consists of reflecting over this universal soul and research harmony by accepting Stoic virtues.

\subsection{Grotius}

Hugo Grotius in On Laws in War and Peace (1625) arrived at pinning down the essence of modern natural law thinking, namely the following properties of mankind and its immunities: i) Sociability of humans; ii) not harming others or taking their belongings; iii) compensate for damages inflicted upon others: iv) "pacta sunt servanda". Interestingly, Grotius finds these 4 principles to be valid for individuals in domestic affairs as well as with regard to the states in international affairs, because they are Right Reason everywhere:

"X. 1. Natural Right is the Rule and Dictate of 1 Right Reason, shewing the Moral Deformity or Moral Necessity there is in any Act, according to its [151] Suitableness or Unsuitableness to a reasonable Nature, 2 and consequently, that such an Act is either forbid or commanded by GOD, the Author of Nature. 2. The Actions upon which such a Dictate is given, are in themselves either 3 Obligatory or Unlawful, and must, consequently, be understood [152] to be either com-[10] manded or forbid by God himself; and this makes the Law of Nature differ not only from Human Right, but from a Voluntary Divine Right; for that does not command or forbid such Things [153] as are in themselves, or in their own Nature, Obligatory and Unlawful; but by forbidding, it renders the one Unlawful, and by commanding, the other Obligatory...” [9].

Grotius derived his four principles of altruism or sociability from universal right reason together with the Jewish-Christian legacy and Greek-Roman philosophy and Roman jurisprudence. He then applied them to both humans and human society, domestically and the international system of states, laying the foundations of public international law.

\subsection{Dworkin}

Ronald Dworkin rejuvenated the natural law school by developing an OUGHTjurisprudence, clustering upon two moral concepts, namely: a) rights; b) law's integrity [10] [11]. The term "right" is much disputed in jurisprudence and political 
theory. It can be employed in both IS-jurisprudence and OUGHT-jurisprudence. Dworkin looks upon the key terms like "justice", "rights" and "entitlements" from the point of view of normative jurisprudence. As a matter of fact, law and morals are inseparable: "law's integrity". Thus, rights always constitute normative trumps, i.e. what people can rightfully claim from government. Let me quote:

(Q1) Moral principle is the foundation of law.

But, which moral system? Kant's, Bentham's, Marx', Rawls'? Moreover, Dwokin says:

(Q2) Without dignity our lives are only blinks of duration. But if we manage to lead a good life well, we create something more. We write a subscript to our mortality. We make our lives tiny diamonds in the cosmic sands [12].

I find this last sentence objectionable, when I think about the children of Yemen who die recently because of lack of milk. The superrich Emirates could easily have flown in this vital lifesaving nourishment to these "diamonds".

One may compare Dworkin's moralism with Kelsen on the concept of justice [13], based on profound insights into the history of morality. The difficulty with dogmatic assertions like these Dworkin quotations is that there is not ONE morality, like a Platonic idea in the ideal world. Typically, there is conflict among the moralities people adhere to. Why would Dworkin's morality-liberal egalitarianism-be THE morality? There is always conflict over basic moral principles. Morals are contestation. Law is ambiguous, amorphous and incomplete, as R.A. Posner argues [14].

Typical of all Dworkin has written is the confusion of IS and OUGHT. What is the foundation of what law? What morals? Whose morals? Chinese law, South African law, Common or Civil Law? Which moral philosophy: Deontological or utilitarianism or procedural?

When we are told to take "right seriously", what rights are we talking about: Hayek's rights regulating laissez faire, Barry's impartiality that is conducive to democratic socialism, etc. The debate over natural law-ordinary law still continues, with Dworkin as its strongest adherent today. His chief critique R. A. Posner today argues that natural law according to (Q1) and (Q2) is merely a set of moral prescriptions, and not juridprudence at all. I agree with Posner in his rejection of Dworkin's confusion of jurisprudence and moral philosophy.

If Dworkin really managed to smash narrow legal positivism of Hart's kind with his rejuvenated natural law philosophy [15], he certainly did not crush the other alternatives, legal realism and legal pragmatism. Neither law nor jurisprudence is a set of eternal Platonic ideas [16].

\subsection{Social Justice}

Dworkin developed his version of liberal egalitarianism, focussing upon the concept of envy and the policy implications of the requirement of socio-economic justice $=$ envy freeness [17]. It led him to a very original theory of auctions and 
assurance. However, it has little relevance for the basic problematic of enhancing real equality in social life-Dworkin's goal. A society and polity based upon envy freeness is completely impractical. Social justice can never start from scratch at an isolated island and neglect merit, which is what Dworkin tries to bypass with the utopian auction and the unrealistic insurance scheme. Dworkin's moralismenvy freeness-is utopian.

The natural law school presents the judiciary with many opportunities for political intervention, including reinterpreting the law. It clearly upsets the Montesquieu balance in favour of the judges at the expense of executives and legislators. No distinction between legal and moral theory can be made. Thus, jurisprudence becomes part of moral philosophy and politics. Dworkin pushed his identity of moralism and jurisprudence to the extreme with his position that correct answers to legal problems can always be found. To many legal scholars, natural law teachings are too open ended-how to identity rights?. Law must somehow be separated from morals, and the role of the judiciary limited to the application of decisions by the executive and the legislature.

\section{Legal Positivism: Favouring the Legal Branch}

Legal positivism stems from Hobbes, who in Leviathan regarded law as the commands of the sovereign. This idea of law belongs clearly to IS-jurisprudence, underlining the will of the state behind law. Following out definition of las as an ordered couple of norm and behaviour, <norm, enforcement>, legal positivism focuses upon the first element, the norms.

Kelsen developed a so called pure theory of law, eliminating all OUGHTjurisprudence, approaching law as a logically coherent system of norm propositions, starting from a Basic Norm, giving normativity to all law and its set of norms, favouring statute law [18].

Hart also looked upon law as rules, separating between primary and secondary rules. Primary rules are imperatives, prohibitions and recommendations. while secondary rules cover several rules of recognition for eliminating merely moral rules. "A rule of recognition" stands for the various markers of law as legality: Parliament, courts, public boards or agencies, etc. [19]. Legal positivism was developed rather differently by Kelsen and Hart. The Hart framework is more flexible than Kelsen's. It makes no assumption of logical coherence and closeness.

\subsection{Kelsen}

A central hypothesis in legal positivism is that of the normativity of law. Norms are imperative sentences, conditional or not, stating what should be done by which persons when and how. These norms constitute valid legal norms when they have objective normativity, according to either the Basic Norm (Kelsen) or Hart' secondary norms. This validity is the subject matter of IS-jurisprudence. It has nothing to do with moral validity, natural law or OUGHT-jurisprudence. 
Kelsen argued famously that legal validity is not only objective but also logical as to its nature [20]. Thus, from the Basic Law at the constitutional top of government to the most elementary regulation at the bottom of the state there is a logical string of necessity, tying the system together [21]. Hart never such exaggerated claims for the logicality of the legal norms, but was perhaps content with subjective Normativity with the judges and police, i.e. the applications of the primary rules are considered valid by the officials.

\subsection{Posner' Negative Critique}

Yet, legal positivism and its ideal of logic normativity hardly stand up to Posner's view of law and jurisprudence. Posner examines existing law or legal order from the point of view of IS jurisprudence [22] [23]. He emphasizes the following features in his polemic against both Dworkin and legal positivism:

a) Change and evolution;

b) Inconsistencies;

c) Lacunas;

d) Conflicting interpretation;

e) Biases.

Legal positivism limits the power of the judiciary, instructing the judges to apply the norms recognized by the executive and the legislature, in accordance with Montesquieu's theory. However, the norms may not be comprehensive enough or coherent. This is what so-called inclusive legal positivism argues-see Waluchow [24]. Judges would then rely upon moral principles, as suggested by Dworkin? Legal realists claim that only the opinion of the Law Maker should count, whether open or hidden in preparatory work.

\section{Legal Realism: Downplaying the Judicial Branch}

\subsection{Legal Machinery}

To the legal realists, law is real regularities in the behavior of state officials, comprising the "legal machinery". In their Is-jurisprudence concerning las as $<$ norm, regularity $>$, the legal realists in Scandinavia did not focus upon validity, which to them meant merely the application and not any form of normativity, objective or subjective (Haegerstroem [25], Ross [26], Eckhoff [27]). Jurisprudence is the study of behavior regularities (Hedenius [28]) or simply facts (Olivecrona).

Legal realism offers a sharp separation between law and morals. Jurisprudence must be IS-jurisprudence and abstain from all forms of moralising. Legal realsists go so far as to claim that the vocabulary of jurisprudence is infested by natural law conceptions. One target of their criticism traditional jurisprudence was the rejection of the notion of a right. Several prominent legal realists argued that "rights do not exist" (Olivecrona [29])

The negation of rights is hardly tenable [30], as we shall see below in Law and Economics and Constitutional Economics. One may speak of normative rights 
and descriptive rights, whether it is a matter of moral theory or jurisprudence [31]. To legal realists, the word "right" is an emotive expression, lacking denotation in real life. But this rejection of the terminology of rights, duties etc. bypasses the usefulness of these terms in systematizing legal theory, a most valuable set of concepts in theoretical jurisprudence. Consider here the Hohfeld scheme and how it can be used to describe the legal order, i.e. existing rights, duties, competencies, etc. [32].

\subsection{Rights}

The general analysis of rights was offered by Hohfeld in the early $20^{\text {th }}$ centurysee Diagram 1 and Diagram 2 for the variety of rights, their opposites and correlatives.

The Hohfeld distinctions are very helpful in analysing the rights that people actually possess in the legal order of a country, like e.g. India and China. The variety of right concepts may also be employed to state recommendations about urgent legal reforms to improve upon peoples' rights. Dworkin never separates between IS-rights and OUGHT-rights, where the gulf may be immense. Instead, he engages in moralism. Yet, all of this is IS jurisprudence, falsifiable or confirmable propositions. Here. "Rights" is merely a key theoretical term for systematically analysing existing legal order-using Hohfeld's elegant conceptual scheme.

\section{Law and Economics}

The rights terminology of Hohfeld is used in Law and Economics, regarding market transactions as the buying and selling of rights. The rejection of the concepts of rights etc. in legal realism is a serious weakness there.

Law and economics school enlarged the perspective of Posner, by theorizing how close law is to the market economy [33]. The foundations of the market economy include contract law, labour law and public regulation. "The size of the market is determined by the range of law". And countries with common law or civil law will perform the best, economically.

The Law and Economics school focuses upon the legal prerequisites of the

Diagram 1. Legal opposites.

\begin{tabular}{cccc}
\hline Right & Privilege & Power & Immunity \\
\hline No-right & Duty & Disability & Liability \\
\hline
\end{tabular}

Note: Privilege is the opposite of duty; no-right is the opposite of right. Disability is the opposite of power; immunity is the opposite of liability.

Diagram 2. Legal correlatives.

\begin{tabular}{cccc}
\hline Right & Privilege & Power & Immunity \\
\hline Duty & No-right & Liability & Disability \\
\hline
\end{tabular}

Note: A right implies that someone else has a duty. A privilege means that someone else has no-right. A power entails that someone else has a liability. An immunity implies that someone else has a disability. 
market economy, including low transaction costs, variability and observability of contracts as well as freedom of labour and the advantages of bourses. The more fungible assets are, the more they can be exchanged and properly valued in markets.

\section{Constitutional Economics}

Here is a theory about law and politics, analysing the pros and cons of alternative political regimes and the impact of rules or norms upon the outcomes of various decision-making processes [34]. It is a more OUGHT than Law and Economics and its origins are to be found in the political economy of Swedish economist Knut Wicksell and his theory about unanimity voting. Constitutional economics also uses the rights terminology a la Hohfeld, especially seeking safeguards against BIG government.

Constitutional economics searches for the rules of decision-making that prevent the Leviathan.

\section{Legal Pragmatism: Judicial Activism}

Remember our definition of "law" as <norm, enforcement>, we can place legal positivism as concentrating upon norm, while legal realism would involve a concentration upon regularity. Legal pragmatism bypasses the norm and focuses upon the judge and how they reason when deciding a case-judge made law.

\subsection{Judge-Made Law}

At the end of the day, it is the judge who decides what is law, using legislation and precedents as well as reason. Thus, Oliver Holmes famous statement:

The prophecies of what the courts will do in fact, and nothing more pretentious, are what I mean by the law [35].

Of course, he meant the "prophecies" in IS-jurisprudence.

\subsection{Law and Efficiency}

Now, Posner argues questionably that judges may tend to take one major consideration into account when deliberating, namely economic efficiency, wealth or utility maximization or Pareto optimality, especially in public regulation as well as tort law [36]. Dworkin denies this, putting in instead Right reason. Legal positivists and realists counter-state simply that judges apply the law - period.

Legal realists tend to distance themselves from legal pragmatism, not in the emphasis upon the decisive role of judges but on the notion of economic efficiency as inherent element in jurisprudence. Law is what the judges decide, whether the decision is efficient or not.

One can distinguish two basic elements in Posner' huge scholarship, namely his idea about law and economics on the one hand and his criticism of Dworkin's moralism. I agree with the second but am skeptical about the first where we are far from Dworkin's rosy theory of Law' empire. We cannot accept the use of 
vague natural law conceptions in order to argue that legal issues are in principle solvable- "the right answer doctrine" or that law is basically morals.

\section{Conclusions}

Montesquieu created the longest lived political theory about freedom and stability, with his theory of separation of powers. It is venerated in polities that have legal review or constitutional review, but also in polities that lack these two mechanisms. In countries with socialist law, which is state interests, or religious law that in Sharia law is "Qadi Justiz" [37], Montesquieu is absent.

Perhaps the separation of powers theory is more important than even democracy theory. Democracies come in several forms, allowing for manipulation of votes often. Law and politics are closely related [38]. But it is very important to insist upon the objectivity of the analysis of law and politics [39], not confusing IS-jurisprudence with OUGHT-jurisprudence. When Dane Ross insists upon the neutrality of IS-jurisprudence, he wants to eliminate concepts like equality, justice and rule of law, but they are central in OUGHT-jurisprudence [40].

To maintain Montesquieu's balance, the teachings of legal positivism and legal pragmatism seem most instrumental. When a country says goodbye to Oriental Despotism, then they rely upon Montesquieu more than anything else. It is often claimed that "oriental despotism" was like "orientalism" invented by European like Montesquieu and other Enlightenment philosophers to uplift Europe and downgrade Asia [41]. But we find despotism in several Central Asian countries still today.

\section{References}

[1] Montesquieu (1989) The Spirit of the Laws. Cambridge University Press, Cambridge.

[2] Shklar, J. (1987) Montesquieu. OUP, Oxford.

[3] Gordon, S. (2005) Montesquieu: The French Philosopher Who Shaped Modern Government. Rosen Central, New York.

[4] Simmons, N. (2008) Central Issues in Jurisprudence. Sweet and Maxwell, London.

[5] Finnis, J. (2011) Natural Law and Natural Rights. Clarendon, Oxford.

[6] Paine, T. (2017) Rights of Man. Createspace Independent, London.

[7] Long, A.A. and Sedley, D.N. (2012) The Hellenistic Philosophers I-II. Cambridge University Press, Cambridge.

[8] Baltzly, D. (2014) Stoicism. In: Zalta, E.N., Ed., The Stanford Encyclopedia of Philosophy (Spring 2014 Edition).

https://plato.stanford.edu/archives/spr2014/entries/stoicism/

[9] Grotius, H. (1625) On Laws in War and Peace. Chap II. http://oll.libertyfund.org/pages/grotius-war-peace

[10] Dworkin, R. (1977) Taking Rights Seriously. Harvard University Press, Cambridge, MA.

[11] Dworkin, R. (1988) Law’s Empire. Belknap Press, Cambridge, MA.

[12] Dworkin, R. (2011) Justice for Hedgehogs. Harvard UP, Cambridge, MA. 
[13] Kelsen, H. (1957) What Is Justice? What Is Justice? University of California Press, Berkeley.

[14] Raz, J. (1979) The Authority of Law. Clarendon Press, Oxford.

[15] Kramer, M. (1999) In Defense of Legal Positivism: Law without Trimmings. Clarendon Press, Oxford.

[16] Posmer, R.A. (1996) Overcoming Law. Harvard University Press, Cambridge.

[17] Dworkin, R. (2002) Sovereign Virtue. Harvard University Press, Cambridge.

[18] Kelsen, H. (1960, 2017) Reine Rechtslehre. [Pure Theory of Law.] Mohr Siebeck, Tuebingen.

[19] Hart, H.L.A. (1994) The Concept of Law. 2nd Edition, Clarendon Press, Oxford.

[20] Kelsen, H. (1960) General Theory of Law and State. Harvard U.P., Cambridge.

[21] Kelsen, H. (1979) Theorie Generale des Normes. [General Theory of Norms.] Manz Verlag. Kramer, M.H., Vienna.

[22] Posner, R.A. (1992) The Problems of Jurisprudence. Harvard U.P., Cambridge.

[23] Posner, R.A. (1999) The Problematics of Moral and Legal Theory. Harvard University Press, Cambridge.

[24] Waluchow, W.J. (1994) Inclusive Legal Positivism. Clarendon Press, Oxford.

[25] Haegerstroen, A. (1953) Inquiries into the Nature of Law and Morals. Almqvist \& Wicksell, Stockholm.

[26] Ross, A. (1934) Virkelighed og Gyldighed i Retslaeren. [Reality and Validity in Legal Doctrine.] Levin \& Munksgaard, København.

[27] Eckhoff, T. (1974) Justice: Its Determinants in Social Interaction. Rotterdam University Press, Rotterdam.

[28] Hedenius, I. (1942) Om raett och moral. [On Law and Morals.] Stockholm.

[29] Olivecrona, K. (1939) Law as Fact. Oxford University Press, London.

[30] Hohhfeld, W.N. (1913) Some Fundamental Legal Conceptions as Applied in Judicial Reasoning. 23 Yale Law Journal, 16. https://doi.org/10.2307/785533

[31] Simmonds, N.E. and Steiner, H. (2000) A Debate over Rights: Philosophical Inquiries. Oxford University Press, Oxford.

[32] Campbell, D. and Thomas, P. (2016) Fundamental Legal Conceptions as Applied in Judicial Reasoning by Wesley Newcomb Hohfeld. Rouledge, London.

[33] Cooter, R. and Ulen, T. (2012) Law and Economics. Addison-Wesley, New York.

[34] Brennan, G. and Buchanan, J.M. (1985) The Reason of Rules: Constitutional Political Economy. Liberty Fund, Washington DC.

[35] Posner, R.A. (2008) How Judges Think. Harvard U.P., Cambridge.

[36] Posner, R.A. (2004) Frontiers of Legal Theory. Harvard U.P., Cambridge.

[37] Weber, M. (1079) Economy and Society I-II. University of California Press, Berkeley.

[38] Waldron, J. (1999) Law and Disagreement. Oxford U.P., Oxford. https://doi.org/10.1093/acprof:oso/9780198262138.001.0001

[39] Weber, M. (1904) Die 'Objektivität' sozialwissenschaftlicher und sozialpolitischer Erkenntnis. [The "Objectivity" of Knowledge in Social Science and Social Policy.] Archiv für Sozialwissenschaft und Sozialpolitik, 19, 22-87.

[40] Ross, A. (1966) Om ret og retferdighed. [On Law and Justice.] Nyt Nordisk Forlag Arnold Busk, København, The Lawbook Exchange, London.

[41] Stanziani, A. (2014) After Oriental Despotism. Bloomsbury Academic, London. 
Submit or recommend next manuscript to OALib Journal and we will provide best service for you:

- Publication frequency: Monthly

- 9 subject areas of science, technology and medicine

- Fair and rigorous peer-review system

- Fast publication process

- Article promotion in various social networking sites (LinkedIn, Facebook, Twitter, etc.)

- Maximum dissemination of your research work

Submit Your Paper Online: Click Here to Submit

Or Contact service@oalib.com 